\title{
TOWARDS THE FIFTH PROVINCE: BRIAN FRIEL'S TRANSLATIONS OF STEREOTYPES ${ }^{12}$
}

\author{
María del Pilar Royo Grasa, Universidad de Zaragoza \\ Email: prg@unizar.es
}

\begin{abstract}
Several cultural and political movements, from the British Empire to political nationalist movements, have repeatedly made use of a wide variety of stereotypes in an attempt to define/ invent the notion of Irishness. My main aim in this paper will be to discuss the portrayal of Irishness in Brian Friel's play Translations (1980). For this purpose, I will elaborate on the play's "translations" of established images/stereotypes. In other words, I will explore how the play tries to challenge and mitigate the reductive and fixing effects of stereotypes from within.

Keywords: Irishness, stereotypes, colonialism, nationalism, Field Day Company, Translations.
\end{abstract}

Título en español: Hacia la quinta provincia: las traducciones de estereotipos de Brian Friel.

Resumen: Varios movimientos culturales y políticos han intentado definir/ inventar la identidad irlandesa mediante el uso de una amplia gama de estereotipos: desde el Imperio británico hasta movimientos políticos nacionalistas. Mi objetivo principal en este artículo será discutir cómo la conocida obra teatral de Brian Friel representa la identidad irlandesa. Con este propósito, me centraré en su "traducción" de imágenes preconcebidas/ estereotipos. Es decir, analizaré cómo esta obra hace uso de estos estereotipos para así poder desafiarlos y debilitarlos.

Palabras clave: 'Irishness', estereotipos, colonialismo, nacionalismo, Field Day Company, Translations.

Cultural identity may alternatively be defined as either a sort of collective "one true self" or as "a matter of 'becoming' as well as 'of being"' (HALL 1990: 223, 225). Thus, while the former notion relies on fixity, the latter sets identity in a constant process of transformation, whereby identity is never completed but shifts according to its context and interplay with other subjects. In Irish studies, identity has been a highly-discussed issue. Definitions of Irishness have constantly fluctuated between essentialism and hybridity, tradition and modernity, nationalism and cosmopolitanism. Especially since their colonization in 1169, the Irish have been subject to several colonial discourses which have privileged the first notion of identity and, therefore, tried to fit them into fixed categorizations. Among the

\footnotetext{
Date of reception: 23 March 2011

Date of acceptance: 22 July 2011

2 The research carried out for the writing of this paper has been financed by the Government of Aragón and the European Social Fund (ESF) (code H05), and the FPU (Formación de Profesorado Universitario) of the Spanish Ministry of Education and Science.
} 
possible colonial discourses, in his book Culture and Imperialism (1994), the prominent postcolonial critic Edward Said highlights Western Imperialism as the most productive force in the creation of established subjects. The maintenance of this 'unalterable' representation is achieved by the use of stereotypes. In Stuart Hall's words (1997: 258, original emphasis), this is a signifying practice which "reduces, essentializes, naturalizes and fixes difference [...] it divides the normal and acceptable from the abnormal and the unacceptable". According to Victorian imperialism, whereas the British were industrious, reliable, mature, rational, adult and masculine, the Irish were indolent, contrary, unstable, emotional, childish, feminine, superstitious, backward and irrational (KIBERD 1996: 30). As can be deduced from these series of binary oppositions, the Irish - the other- became trapped in a subservient position. Their alleged inferiority deprived them of any capacity to govern themselves. As many authors affirm (cf. BHABHA1994; SAID 1994; HALL 1997), these representational practices contributed to justifying the imperialist 'civilizing mission' as being fair and necessary.

In keeping with Fanon's ideas, Said compared Ireland's decolonizing process with similar situations undergone by other former colonies of the British and French Empires. In this long-term process towards independence, Said (1990: 83) distinguishes the rise of nationalist and independence movements as the first moment of resistance to imperialism. Not surprisingly, in the Irish context, the aforementioned colonial oppressive situation gave rise to the emergence of political as well as cultural nationalist movements such as the Sinn Fein Party or the Irish Cultural Revival. These movements claimed Ireland's independence by asserting the uniqueness and centrality of their native culture, a culture that had been denigrated by the imperial power (HARRINGTON 1991: xi). As a strategy to contradict the stereotypes which had been imposed on them, the Revival turned the negative connotations of these stereotypes into positive features. Thus, spirituality, communion with nature and mysticism stopped being a mark of backwardness and became instead a positive feature which made up for the lacks of the British. However, this method presents weak points. Stuart Hall (1997: 274; original emphasis) asserts: "the problem with the positive/negative strategy is that adding positive images to the largely negative repertoire of the dominant regime of representation [...] does not necessarily displace the negative". Said (1994: 276) convincingly highlights that nativism/nationalism makes the same mistake as imperialism, that of fixity and essentialization: "to accept nativism is to accept the consequences of imperialism, the racial, religious, and political divisions imposed by imperialism itself". Therefore, as the literary critic Declan Kiberd (1996: 32) argues, the revival's strategy implied, in turn, remaining within the conventions and patterns constructed and imposed by the colonizers.

In a pamphlet published by the Field Day Theatre Company, Said (1990: 83) affirmed that the only alternative to a continuation of a relation of dominance is "a transformation of social consciousness beyond national consciousness". This transformation should be achieved during the second moment of the decolonizing process: the so-called "liberation" stage. Although, as some revisionist groups would affirm, Ireland's decolonizing process ended at the moment in which the country became a Free State in 1922, the subsequent subdivisions within the country seem to confirm Said's assertion that liberation had not reached its end yet. The euphoric hope of a prosperous new beginning after Independence 
ended up in disillusionment and frustration. Ireland could not escape the outbreak of another famine, emigration and economic difficulties. The impossibility to reintegrate the national territory completely left the Northern part, still under British rule, split from the Southern part, which came to be known as the Republic of Ireland (KIBERD 1996: 263). The tensions between both territories increased throughout the 1970s when the Irish language stopped being a compulsory subject in the schools of the republic and when this latter became a member of the European Economic Union in 1972 (KIBERD 1996: 574). Besides, a circle of violence and internal subdivision between loyalists and republicans was devastating the northern part. Judging from all these issues, it would be no exaggeration to affirm that, by the 1970s, Ireland's "liberation" process was still a rather titanic task.

In 1980, the Field Day Theatre Company was set up in Derry to challenge nationalist, revisionist, and imperialist ideas. They defined themselves as a cultural movement, which was mainly concerned with the asphyxiating circle of violence and sectarianism that was enshrouding the social and political situation in Northern Ireland. Among the aims of this movement was the identification and subsequent demythologization of the fundamentalist rhetoric which had been used and abused to define the Irish, and which somehow made "each community see the other as a threat to its existence" (DEANE 1990: 16). They sought to create an artistic 'fifth province', that is, an inclusive mental place where prejudices and barriers could be destroyed through art (BINNIE 1991: 565). The debut of Brian Friel's Translations (1980) in Derry constituted the company's first attempt to bring about this ambitious artistic and reconciling project. Evoking Bernard Shaw's John Bull's Other Island, Brian Friel plays with stereotypes and dramatizes the themes of homecoming, love and colonial rivalry. The play moves back in time and sets the action in 1830, a transitional stage during which the more traditional and rural Ireland was being redefined, if not erased, by the Anglicizing Ordnance Survey and the substitution of national schools for hedge schools. Just as was happening in the current context in which the play was written and released, the very notion of Irishness was by then halfway between a fixed identity and a promise of becoming. My main endeavour in this essay will be to explore how the play tries to solve this tension tentatively. For this purpose, I will analyze and discuss the portrayal of Irishness in the play by focusing on its use of some of the aforementioned prefigured images of Ireland, that is, its stereotypes.

The very title of the play already foreshadows the play's colonial theme. The action of translation may be equated with the strategy of stereotyping. The Oxford Dictionary defines 'translate' as "to turn from one language into another" and "to interpret, explain; to expound significance of (conduct, gestures, etc.); also, to express (one thing) in terms of another" (MURRAY 1989: 409). In this sense, the main function of translation is to put the other into one's own terms so as to understand it. To this definition, one should add that the "root-meaning of 'translate' was 'conquer': the Romans conquered not only Greece but the Greek past, which they refitted for their own purposes"” (KIBERD 1996: 624). Similarly, Csilla Bertha (2006: 159) describes "naming or renaming" as "one of the most ancient forms of taking something or someone into possession". To quote Homi Bhabha (1994: 66), the stereotype "is a form of knowledge and identification that vacillates between what is always 'in place', already known and something that must be anxiously repeated". In other words, the stereotype is just one particular feature which attempts to control and 
define a whole group of people according to already known and set conventions, in such a way that the threat of the unknown is mitigated. Thus, like translation, stereotypes read/ turn the unknown into the known. In Friel's play, the Anglicizing of Gaelic place-names through the Ordnance Survey is a clear example of this strategy: the British rename the land in order to know it and master it. This allows the colonizer (Captain Lancey) to threaten the colonized in the last act of the play and say to him: "I know you. I know where you live" (2517). Nevertheless, due to the fact that stereotypes are just an oversimplification, they need to be continuously reaffirmed; something which the New Survey will guarantee. Hence, like the very act of translation, the translation of place-names becomes a tool to remodel and conquer the other repetitively. In this sense, the translation of the Gaelic place names becomes an act of colonial dispossession and subjugation.

However, as I shall argue in this essay, translation is the plausible strategy which the play deploys in order to lay the bedrocks of Field Day's fifth province. In a chapter of Kiberd's path-breaking book Inventing Ireland: the Literature of the Modern Nation (1996), the Irish critic regards the act of translation as essential for the invention and renovation of Ireland. If we take Kiberd's definition of the act of translation as "a rewriting" (629), it could be argued that this play makes use of stereotypes as its point of departure in order to translate/rewrite them. Thus, the play would re-conquer them for its own purposes. At first sight, the depiction of the characters in the play seems to comply with the stereotypes imposed by the imperialist discourse: Hugh and Jimmy embody the alcoholic Irishman; Sarah's "waiflike appearance" (2477) and Jimmy's lack of personal hygiene -"he never washes" (2478) - seem to confirm the stereotypical figure of the dirty Irish savage; and, as Kiberd rightly remarks, the fact that the pupils are adults evokes the stereotype whereby the Irish are infantilized (1996: 615). Furthermore, the setting of the play in a hedge school in the rural town Baile Beag seems in accordance with the mysticism and provincialism encouraged by the Celtic Revival. The West was regarded as the cradle of Irishness, the only place which had not been polluted by modernity yet, where the Irish lived in contact with nature and the Irish language was preserved. In sum, one may be tempted to believe Owen when he states "I can't believe it. I come back after six years and everything's just as it was! Nothing changed! Not a thing!" (2491). However, the adjectives used to describe the farming tools as in the "disused barn" or the "broken and forgotten implements" (2477) highlight the passing of time and call into question the preservation of a strong peasant tradition. Far from supporting these stereotypes, Translations plays with them or rather translates them. This is especially achieved through the use of irony. For instance, the fact that Jimmy "is a bachelor in his sixties" (2478) makes his nickname -the 'Infant Prodigy'- become fully ironic. Similarly, when Captain Lancey, misguided by the stereotype which labels the Irish as childish and backward, tries to explain the remapping mission in an oversimplified way, he makes a fool of himself. Another fact worth mentioning is that even the authority of the stage directions is questioned. Doalty is introduced as "an open-minded, open-hearted, generous and slightly thick young man" (2482), a description that leads us to think that he might play the role of the noble peasant; by contrast, his actual behaviour contradicts the very fixity that this characterization has led us to expect: he ill-treats Jimmy by calling him "eejit" (2483) or "lazy" (2484) and refuses to listen to Jimmy's advice (2484). In sum, it could be argued that in its attempt to build a fifth province, Translations ironically plays 
with consolidated stereotypes so as to translate and challenge them. In what follows I will elaborate on this matter.

Broadly speaking, stereotypes imply a two-way process. As Stuart Hall (1990: 226) suggests, they vary according to the position from which they are formulated: cultural identities "are the points of identification, the unstable points of identification or suture, which are made within the discourses of history and culture. Not an essence but a positioning". Hence, it becomes understandable that the British colonizers are not free from categorization either. The barrier which separates these two groups is illustrated by language -they cannot understand each other- as well as by cultural factors or prejudices. Sentences such as "that is the image of them" (2483), uttered by Bridget after Doalty has imitated the British soldiers, or "aren't they all at some level?" (2505) asked by Manus when he refuses to talk in English to Yolland demonstrate that, for the Irish, the British soldiers represent oppression, and stupidity; in other words, the other. This last remark is also hinted at by Yolland when he says to Owen "even if I did speak Irish I'd always be an outsider here, wouldn't I? [...] The private will always be... hermetic" (2501). Yet, as Elizabeth Butler convincingly remarks, this gap is partially bridged by the figure of the decent chap and the subsequent weaving of a homosocial relationship between Yolland and Owen. Yolland represents the decent chap: he is not a normal soldier but "a soldier by accident" (2493). According to Butler (2001: 54), the figuring of Yolland as the decent chap is reinforced when we compare him with the other British soldier: Captain Lancey. Unlike Lancey, Yolland is not authoritative, and is interested in knowing the native culture. He does not agree with the renaming of the land and loves Ireland. This demonstrates that not all the soldiers can be grouped under the same stereotype. Secondly, the homosocial relationship between Owen and Yolland points to the possibility of reconciliation between the self and the other; instead of having an antagonistic relationship, they demonstrate that both sides can understand and, in a way, complement each other. This union is epitomized in Owen's new name after his 'baptism': "Roland" (2505), which inevitably brings to mind Homi Bhabha's (1994: 113, 116) figure of the hybrid who introduces "a disturbing questioning of the images and presences of authority" and "breaks down the symmetry and duality of self/other, inside/outside". Therefore, the fact that the hybrid cannot fit into any established pattern problematizes the validity of any stereotype and thus of a fixed identity. This may explain why Owen is seen as a betrayer or why Yolland's hibernophilia sounds too excessive. If we let ourselves be guided by the traditional portrayal of the English and Irish in Irish drama, Owen and Yolland's roles would immediately be defined. As is suggested by Manus' suspicious behaviour towards his brother at the beginning of the play, Owen may partially evoke the figure of the "informer", that is, those whose "conflicting loyalties" pointed "higher than English oppressors on the scale of melodramatic evil" in Irish plays (BUTLER 2001: 16). Yolland would become "the Englishman as cultural [romantic] tourist" (43); even if he cannot enter the tribe, he can "learn how to decode [it]" (2501). Unfortunately, Yolland's final disappearance seems only to confirm that such a hybrid relationship between Owen and Roland turns out to be incomprehensible in a context where both the British and the Irish characters still base their relationship with the other on stereotypes.

In keeping with these ideas, I would like to draw attention to the stereotype which has traditionally identified Ireland with femininity. Following my argument that Translations 
makes use of stereotypes in order to undermine them, I would like to emphasize the close relationship between the relevance of the ritual of naming in the play and the depiction of Sarah. Aaron Kelly (2008: 154) interprets Sarah's strivings to learn her name and final muteness as the example which "clearly broaches the key issues of losing one's own language and culture and being redefined by someone else's terms and power". This idea brings about the following question: who redefines/ renames Sarah? I can only agree with Kelly's ideas when he interprets this relation of dominance, not only as a direct consequence of imperialism, but also as a result of the gender politics enforced by her own local community. In Translations, Sarah is, without any doubt, the character who is spoken for. On the one hand, like the Irish, she is subject to the ruler's representation. Taking Sarah as an emblem of the Irish nation, Marisol Morales draws an analogy between the character's progressive acquisition of her own voice followed by her subsequent final muteness and the process of Anglicizing place-names. Morales (2003: 196) offers two readings of Sarah's final reluctance/ inability to say her name to Captain Lancey. On the one hand, this silence may be read "as an act of resistance to colonialism and to the new language that will be imposed on the villagers". This muteness could thus symbolize her refusal to say her name so that the captain may not turn it into English as he has done with the rest of Irish place-names. In relation to this last remark, Morales offers an alternative interpretation of the character's dysfunction as a symbol of dispossession and oblivion of the Irish language. Therefore, Sarah's muteness stands for "an echo of the silence that will reverberate throughout the whole Gaelic-speaking community" (196).

On the other hand, several are the critics (cf. O' BRIAN and CAIRNS 1991) who have criticized the symbolic role of women in colonial and postcolonial cultures. To use Butler's terms, women may be regarded to have traditionally played the role of "internal others" 3 subject to the parameters and myths of their own local community. Not denying that a return to the myth/ the origins may be a reasonable attempt to reaffirm one's own primordial position and, thus, his/her rightful belonging to the place, Seamus Deane (1990: 17) affirms: "the search for origin, like that for identity, is self-contradictory. Once the origin is understood to be an invention, however necessary, it can never again be thought of as something 'natural'. A culture brings itself into being by an act of cultural invention that itself depends on an anterior legitimating nature". Other critics such as David Cairns, Toni O'Brian Thomson (1991), Elin Ap Hywel (1991) and Lauren Onkey (1997), among others, are even more disapproving, and bring to the fore the double morality of Irish gender politics. According to Onkey, the role of women in Irish national myths mischievously dignifies and elevates them. They come to embody the Irish nation, and thus become images of cult. However, this strategy relegates them into a submissive position. They are turned into the nation's "property" (1997: 161). As a consequence, their individuality is erased; their actions come to represent the whole community, which, in turn, become their rulers and judges. All these ideas bring to mind Spivak's (1988: 287) reflection on the role played by women in her essay "Can the subaltern speak?", when she affirms: "both as object of colonialist historiography

\footnotetext{
In her 2001 book Ireland's Others. Gender and Ethnicity in Irish Literature and Popular Culture, Butler specifies: "the Others of my title are numerous, and they are both real and fictive. Ireland is accustomed to being stigmatized as the feminized object of English discourse, but in women, gays, abused children, travellers and the working class it has produced its own internal Others" (2001: 7).
} 
and as subject of insurgency, the ideological construction of gender keeps the male dominant. If, in the context of colonial production, the subaltern has no history and cannot speak, the subaltern as female is even more deeply in shadow". Sarah would undoubtedly be one of the female characters who remains in the shadow. Critics have associated her with different traditions: while Morales (2003: 196) identifies her with the Hebrew figure Sarah, who was chosen by God to be "the mother of all nations," for Seamus Heaney (1991: 559), Sarah stands for the Irish mythical figure known as Cathleen-Ní-Houlihan, who was widely used as an emblem of Ireland by Irish nationalist movements and authors such as Lady Gregory, William Butler Yeats or Ethna Carbery, among others. Besides, there are several instances in the text which invite the reader/ spectator to interpret Sarah as a mythological figure: her unspecified age, she was "any age from seventeen to thirty-five" (2477); her deep knowledge of the geography of the place (she is aware of every account that takes place in the community such as the place of celebration of the christening or Maire's encounter with Yolland); and finally, and most remarkably, the unspecified language in which she communicates with Manus. Notably, the play draws attention to the constructed nature of Sarah's naming process, and, what is even more significant, to the fact that this is a product of male agency. The stage directions at the beginning of the play already create a male-dominated world: "the room is comfortless and dusty and functional -there is no trace of a woman's hand" (2477). This description conveys a patriarchal mentality which assigns gender roles: women are the sentimental ones who do the cleaning, while the public sphere becomes men's domain (as I have already mentioned, hedge schools constituted the centre of the Irish tradition). Besides, it is worth pointing out that it is Manus that teaches/ gives Sarah a name, and that her muteness is due to the fact that "all her life she has been considered locally to be dumb and she has accepted this" (2477). Furthermore, despite her efforts to call Manus' attention and please him, she is quickly forgotten: "I said it Manus! [MANUS ignores SARAH. He is much more interested in OWEN now]" (2492). The stage directions bring to the fore that she is let down by Manus, who "addresses her as he did in Act One but now without warmth or concern for her" (2513). All these arguments lead us to agree with Aaron Kelly (2008: 154) that Sarah "was muted by her local community to begin with before the translation of that community into English".

Similarly, Maire is the other outstanding female 'subaltern' character of the play. She reasonably evokes one of the female protagonists in Dubliners: Eveline Hill. Like Maire, the Joycean character lives in a male-dominated atmosphere: her mother is dead and she is her father's prey (JOYCE 1996: 39). Her only possibility of freedom is her elopement to Buenos Aires with an Irish sailor. By the end of the short story, Eveline becomes trapped in a state of paralysis; she refrains from leaving her family and country and stays. Maire embodies the tension between a fixity which enslaves her (she has to take care of her brothers, lives in poverty) and a desire to move on. For her, Yolland also represents her chance to break free from poverty and confinement. However, as was the case of Owen and Yolland, stereotypes doom her relationship with him. On the one hand, they devaluate the true nature of their love. At first sight, the attraction between Maire and Yolland demolishes social and cultural barriers. This idea is first suggested by the stage directions which open the love scene in the second act. Although, this scene, like all of the others scenes of the play, also occurs in the schoolroom, the directions concerning the lightning and composition of the 
stage invite the reader/ spectator to play down the relevance of this place: in this case "it would be preferable to lose-by lightning-as much of the schoolroom as possible, and to play the scene down front in a vaguely 'outside' area" (2508). The couple comes to attract the audience's attention. The play places them in a kind of neutral area (neither the schoolroom nor the dance), and thus distances Yolland and Maire from the dramatic community as they keep on "running and laughing [...] hand in hand". The change of music also contributes to creating an intimate and distinctive atmosphere. (2508). Besides, Yolland and Maire's love scene is depicted as something challenging to the community (they are escaping from the dance); something which manages to transcend the social and moral codes of the community. In short, the law represented by the hedge-school is left in the background and the focus is now on Yolland and Maire. They stop being anonymous types in the community to become two individuals holding hands. However, a deep analysis would reveal that their attraction is, as Onkey points out (1997: 164), grounded on "misunderstanding". Yolland is charmed by a mystified vision of Maire. While he wants to stay with Maire in Baile Beag "always", Maire wants him to "take [her] away" (2511). But, above all, it is her community that aborts any chance that Maire and Yolland can be together (it is suggested that the Donnelly twins have probably killed Yolland). Again, Maire and Yolland's transcultural relationship is perceived as dangerous by a community still governed by stereotypes and binary oppositions. In Butler's words (2001: 56), "Maire's affections look to the local people like a cynical and demystified enactment of the heterosexual colonial allegory". To put it differently, for her community, Yolland represents the masculine colonial power who tries to conquer the feminine Ireland; therefore Maire's affection for him is perceived as a kind of betrayal. As is explained by Onkey (1997: 166), since Maire embodies the nation, she cannot freely fulfil her wishes. This is suggested by Jimmy when he says to Maire: "Do you know the Greek word endogamein? It means to marry within the tribe. And the word exogemein means to marry outside the tribe. And you don't cross those borders casually -both sides get very angry" (2522). Yet, rather than supporting this view, the tragic ending of the play suggests that the community has overreacted against Marie's sexual transgression. To quote Onkey again (1997: 166), “the impending reprisals of Lancey's troops indicate that policing Maire's desires will make life worse in Baile Beag". In sum, it could be argued that the play challenges the trope of "mother Ireland" as embodied by the character of Maire. The development and self-consciousness of the play question the unfair oppressive power that this fixed image exerts on individuals.

Finally, special attention should be given to the function of language in the play. The play's introduction of Latin and Greek mythology and language is open to interpretation. According to the medieval historian Geoffrey of Monmouth, Brutus - the legendary founder and first King of Britain- was a descendant of the Trojan prince Aeneas. Throughout history, this genealogical connection between the two empires, the Trojan and the British, has acquired positive and negative connotations. On the one hand, it came to evoke "decadence" in the nineteenth century. This point is reinforced by Aeneas' treachery and subsequent downfall of Troy, together with the fact that Rome was the place where Christians were "thrown to the lions". On the other hand, Rome also embodied the prestigious notion of "empire". During the nineteenth century, the imperialist rhetoric chose to ignore the negative connotations that I have just mentioned, and the analogy was used as evidence of Britain's prestige and power 
(BUTLER 2001: 100-101). In Friel's play, this latter association becomes fully ironic. As is pointed out by Butler (117), the Irish characters of the play seem to associate the British soldiers with the Romans. For example, Maire addresses Yolland in Latin: "Tu es century in -in -in exercitu Britannico" (2509). Yet, none of the British soldiers understand Latin or Greek. Nor are they familiar with the classics, which may signal their cultural decadence and, to quote Butler again, may offer these soldiers as "Friel's polemical reversal of the stereotype of English civilians and Irish barbarians" (2001: 111). This stereotype is clearly challenged through the connection between Ireland and Mediterranean cultures, a link which is explicitly established by Hugh when he apologizes for not knowing the canonical English poet Wordsworth: "we feel closer to the warm Mediterranean. We tend to overlook your island" (2502). This statement about English literature diminishes the imposed centrality of the colonizer's culture and displaces it to a peripheral position. Thus, the mutability and relativity of all categorizations is brought to the fore. As authors such as Said (1994: 127) suggest, the ethnocentricity of a culture is the result of a never-ending circularity in which it is the one who is empowered who sets the rules: "we are dominant because we have the power (industrial, technological, military, moral), and they don't, because of which they are not dominant; they are inferior, we are superior... and so on and on". In a word, it could be argued that, even if Jimmy sounds ridiculous when he affirms that he plans to marry goddess Athene (1520), the Irish characters' knowledge of the classics also helps to breach the triumphalist bond between Britain and Rome, and put to shame the British characters' cultural background.

Yet, authors such as Scott Boltwood have offered a less positive interpretation of the characters' proficiency in Latin and the classics. Boltwood's synchronic analysis of Translations establishes a mutually exclusive relation between the Irish characters' knowledge of Greek and their familiarity with Gaelic mythology. He concludes that, by the time the play is set, "Irish culture ha[d] already lost its distinctive Gaelic heritage" (2007: 155). To put it differently, Boltwood points out that, even though, as I have already mentioned, the theme of the Ordenance Survey leads to make a postcolonial reading of Friel's play, some Irish characters are also to blame for the progressive loss of Gaelic traditions. To exemplify this idea, Boltwood highlights the indifference shown by Manus towards the Irish myth of Grania, and the lack of Irish culture in the curricular programme of the hedge school. As Boltwood remarks (2007: 158), "Hugh comes to accept the necessity to teach in English because he realizes that only the language of instruction will change". I do not intend to emphasize that, through this strategy, Friel's play is lamenting the loss of Irish culture, and, thus, carrying out an absolutist call for its recovery. On the contrary, what this strategy brings to the fore is that languages and cultures inevitably evolve. Furthermore, the fact that it is the Irish who speak Latin, and not the British, brings to the fore the main irony of the play, namely that, as has been remarked by Butler (2001: 118), the play needed to be written in English for the most of the audience to understand it. This assertion may suggest some lamentation and reproach. However, Friel's choice to write it in English may just as well be understood as a strategy to "write back"4. This idea is explicitly stated

4 The appropriation of English by postcolonial countries is a widely discussed topic in the seminal work published by Bill Aschroft, Gareth Griffiths and Helen Tiffin entitled The Empire Writes Back. Theory and Practice in Post-colonial Literatures (1989). 
by Hugh, when he advises, they "must learn the new names" and make them their own (2521). This is precisely what the play does, it "translates a Gaelic past into an Anglo-Irish present" (MCGRATH 1999: 195). To put it differently, just as the characters of the play make Latin their own, the play uses the colonizer's language to question imposed notions of Irishness derived from colonization. In this sense, as is also argued by F. C. McGrath, the play attempts to offer a critical redefinition of Irishness.

By way of conclusion, it could be argued that Translations questions stereotypes imposed both by Western Imperialism and by Irish nationalism from within. It distances itself from any possibility of a fixed notion of Irishness through the use of irony. The play denounces the negative effects of stereotypes, which build up all sorts of barriers between the colonizers and the colonized and destroy any possibility of communion, such as the one woven by the relationship between Owen and Yolland, and that between Maire and Yolland. The play suggests that the insistence to perpetuate the stereotypes built by both monolithic discourses will only prevent that reconciliation from happening, which will inexorably bring more and more violence and destruction. As Hugh says to Maire, "always is a silly word" (2522).

\section{REFERENCES}

AP HYWEL, E. 1991. "Elise and the Great Queens of Ireland: 'Femininity' as Constructed by Sinn Féin and the Abbey Theatre, 1901-1907." Gender in Irish Writing. Eds. D. CAIRNS and T. O’ BRIAN JOHNSON. Milton Keynes; Philadelphia: Open University Press. 23-39.

Ashcroft, B., et al. 1989. The Empire Writes Back. Theory and Practice in Post-colonial Literatures. London and New York: Routledge.

Bertha, C. 2006. "Brian Friel as Postcolonial Playwright." The Cambridge Companion to Brian Friel. Ed. A. ROCHE. Cambridge: Cambridge University Press. 154165.

BнaвHA, H. 1994. The Location of Culture. London \& New York: Routledge.

Boltwood, S. (2007) 2009. Brian Friel, Ireland and the North. Cambridge: Cambridge University Press.

Binnie, E. (1988) 1991. "Brecht and Friel." Modern Irish Drama. Ed. J. P. HARRINGTON. New York-London: Norton Critical Edition. 564-570.

Butler Cullingford, E. 2001. Ireland's Others. Gender and Ethnicity in Irish Literature and Popular Culture. Cork: Cork University Press in association with Field Day.

Cairns, D. And O'Brian Johnson, T. eds. 1991. Gender in Irish Writing. Milton Keynes; Philadelphia: Open University Press.

DeAne, S. 1990. "Introduction." Nationalism, Colonialism and Literature: A Field Day Company Book. T. EACLETON, et al. Minneapolis, London: University of Minnesota Press. 3-19. 
Friel, B. (1980) 2006. Translations. The Norton Anthology of English Literature, Vol. F, The Twentieth Century and After (eight edition). M. H. ABRAMS, et al. New York and London: Norton. 2477-2522.

Hall, S. 1990. "Cultural Identity and Diaspora." Identity, Community, Culture, Difference. Ed. J. RUTHERFORD. London: Lawrence and Wishart Ltd. 222-237.

---. 1997. "The Spectacle of the Other." Representations: Cultural Representations and Signifying Practices. Ed. S. HALL. London: Sage. 223-290.

Harrington, J. P. 1991. "Preface.” Modern Irish Drama. Ed. J. P. HARRINGTON. New York-London: Norton Critical Edition. $\mathrm{x}$-xiv.

HeAnEy, S. (1988) 1991. “Introduction.” Modern Irish Drama. Ed. J. P. HARRINGTON. New York-London: Norton Critical Edition. 557-559.

Joyce, J. (1914)1996. “Eveline.” Dubliners. London: Penguin Books Ltd. 37-43.

Kelly, A. 2008. Twentieth-Century Irish Literature: A Reader's Guide to Essential Criticism. New York: Palgrave Macmillan.

KIBERD, D. 1996. Inventing Ireland: the Literature of the Modern Nation. London: Vintage.

Morales Ladrón, M. 2003. “Gender Relations in Brian Friel's Translations: ReMapping the Postcolonial Agenda." The Representation of Ireland/s. Images from Outside and from Within. Ed. R. GONZÁLEZ. Barcelona: PPU. 193-202.

Mcgrath, F.C. 1999. Brian Friel's (Post)Colonial Drama: Language, Illusion, and Politics. Syracuse: Syracuse University Press.

Murray, J. A.H., et. al. 1989. The Oxford English Dictionary. Second Edition. Volume XVIII (Thro-Unelucidated). Oxford: Clarendon Press.

OnkeY, L. 1997. "The Woman as Nation in Brian Friel's Translations." Brian Friel: A Casebook. Ed. W. KERWIN. New York and London: Garland Publishing, Inc: 159-174.

SAID, E. W. (1988) 1990. "Yeats and Decolonization." Nationalism, Colonialism and Literature: A Field Day Company Book. T. EAGLETON, et. al. Minneapolis, London: University of Minnesota Press. 69-95.

---. 1994. Culture and Imperialism. London: Vintage.

Shaw, B. (1907) 1984. John Bull's Other Island. London: Penguin Books Ltd.

SpIVAK, G. C. 1988. "Can the Subaltern Speak?" Marxism and the Interpretation of Culture. Eds. C. Nelson and L. Grossberg.Urbana, IL: University of Illinois Press. 271-313. 